Jurnal Gizi dan Dietetik Indonesia (Indonesian Journal of Nutrition and Dietetics) Vol. 8, No. 1, 2020: 9-21

\section{Associated factors of adolescents malnutrition in junior high school student}

\author{
Nuryani ${ }^{1}$, Yeni Paramata ${ }^{2}$ \\ ${ }^{1}$ Nutrition Study Program, Faculty of Public Health, University of Gorontalo \\ Jalan AA Wahab (Ex Jend Sudirman), Limboto Subdistrict, Gorontalo District, Indonesia, 96211 \\ ${ }^{2}$ Public Health Sciences Study Program, Faculty of Public Health, University of Gorontalo \\ Jalan AA Wahab (Ex Jend Sudirman), Limboto Subdistrict, Gorontalo District, Indonesia, 96211 \\ ${ }^{*}$ Corresponding author: nuryanigz@gmail.com
}

\begin{abstract}
ABSTRAK
Latar Belakang: Remaja merupakan kelompok usia yang rentang mengalami malnutrisi baik gizi lebih maupun gizi kurang yang disebabkan oleh pertumbuhan fisik yang cepat, perubahan hormonal untuk system reproduksi dan perubahan psikosial.

Tujuan: Tujuan penelitian ini untuk mengkaji sejumlah faktor yang mempengaruhi kejadian malnutrisi pada remaja.

Metode: Desain penelitian cross sectional study yang diselenggarakan di MTS Negeri Model 1 Limboto. Pengambilan sampel menggunakan tekhnik accidental sampling sejumlah 251 remaja. Variabel penelitian berupa status gizi remaja, status sosial ekonomi, pengetahuan, sikap dan perilaku gizi pada remaja. Analisis hubungan antara variabel menggunakan uji chi square test dengan nilai $\alpha=0.05$.

Hasil: Hasil penelitian menunjukkan sebanyak 10,0\% remaja mengalami stunting, 23,5\% remaja mengalami obesitas, $72,5 \%$ pengetahuan gizi kurang, 41,8\% sikap gizi seimbang negative dan $45,4 \%$ perilaku gizi seimbang yang tidak baik. Analisis uji chi square menunjukkan pendidikan ayah berhubungan dengan kejadian stunting pada remaja $(p=0,001)$, namun analisis hubungan social ekonomi dengan kejadian stunting dan obesitas remaja berturut - turut pendidikan ibu ( $p=0,051$ dan $p=0,647)$, pekerjaan ibu ( $p=0,385$ dan $p=0,206)$, pendapatan keluarga $(p=1,000$ dan $p=0,061)$, riwayat pengasuhan $(p=$ $0,496$ dan $p=0,525)$, jumlah saudara ( $p=0,131$ dan $p=0,903)$, jenis kelamin $(p=0,298$ dan $p=1,000)$, pengetahuan $(p=0,767$ dan $p=0,447)$, sikap $(p=0,656$ dan $p=0,805)$ dan perilaku gizi $(p=1,000$ dan $p=0,268$ ) tidak berhubungan dengan kejadian stunting dan obesitas pada remaja.
\end{abstract}

Kesimpulan: faktor social ekonomi yakni pendidikan ayah berhubungan signifikan dengan kejadian stunting pada remaja.

KATA KUNCI: malnutrisi; pengetahuan; perilaku; sikap; sosial ekonomi

\begin{abstract}
Backgrounds: Adolescents are an age group that vulnerable experiencing of malnutrition both over nutrition and undernutrition caused by rapid physical growth, hormonal changes to the reproductive system and psychosocial changes.

Objectives: The purpose of this study was to examine the socioeconomic factors that influenced the incidence of malnutrition in adolescents.

Methods: The design study was cross sectional study conducted in MTS Model 1 Limboto State. Sampling was used an accidental sampling technique with 251 adolescents. Research variables were included nutritional status, socioeconomic status, knowledge, attitudes, and nutritional behavior. Analysis of the association between variables using the chi square test with a value $\alpha=0.05$. The results showed as many as $10.0 \%$ of adolescents were stunted, $23.5 \%$ of adolescents were obese, $72.5 \%$ low nutritional knowledge, $41.8 \%$ negative balanced nutrition attitudes and $45.4 \%$ poor balanced nutrition behavior. Analysis chi square test was showed the father education related to the incidence of stunting in adolescents $(p=0.001)$, but analysis of social economy with the incidence of stunting and obesity in adolescent respectively maternal education ( $p=0.051$ and $p=0.647$ ), mother occupation ( $p=0.385$ and $p=0.206)$, family income $(p=1,000$ and $p=0.061)$, caregivers $(p=0.496$
\end{abstract}


and $p=0.525)$, number of siblings ( $p=0.131$ and $p=0.903)$, gender $(p=0.298$ and $p=1,000)$, nutrition knowledge $(p=0.767$ and $p=0.447)$, attitudes $(p=0.656$ and $p=0.805)$ and nutrition behavior $(p=1,000$ and $p=0.268$ ) were not related to the incidence of stunting and obesity in adolescents.

Conclusion: It was concluded that socioeconomic factors namely father education were significantly related to the incidence of stunting in adolescents.

KEYWORDS: attitude; behavior; knowledge; malnutrition; social economy

\section{INTRODUCTION}

Adolescence is a very important period in supporting growth and development in the stages of the life cycle (1). The fulfillment of adequate nutrition is very important for optimal growth and development for adolescents (2). Adolescents range of experience nutritional problems both the problems of malnutrition either over nutrition or under nutrition problems are caused by changes in physiological and social changes (3). Changes in rapid somatic growth, problems related to the development of sexual maturity and difficulty in distinguishing norm values are associated with the risk of health problems in adolescents (4). The close linkages between biological development in adolescence until adults may be a chance of prevention of health problems in adulthood (5).

Inadequate nutrients intake have an impact on growth retardation, stunting and developmental failure, while in the adolescents period experience rapid growth and development, that causes nutrient requirements also increase and the fulfillment of macronutrients and micronutrients becomes very important $(2,6)$. Malnutrition in adolescents has consequences for cognitive development in the form of decreased learning abilities, poor ability to concentrate and failure in school performance (7). Adolescent malnutrition includes malnutrition and over nutrition (8). More than the last two decades the increased prevalence of obesity and overweight in adolescents (9). Obesity in adolescence increases the risk of obesity at age adults and this will also lead to an increased risk of cardiovascular disease and syndrome metabolic (10). Many developing countries currently face the problem of double burden nutrition, namely the issue of overweight and obesity emergencies along with the high prevalence of stunting and deficiencies of micronutrients (11).
Besides, the issue of adolescent stunting nutrition is also important, because of the impacts for the next stage of the life cycle. Stunting is a condition of a chronic nutritional problem that shows a past nutritional history and is heavily influenced by environmental and socioeconomic factors (12). Many adolescents in developing countries experience malnutrition problems that cause adolescent ranges to experience health problems and premature death. Numerous studies show high stunting and thin adolescents in developing countries (13). Therefore, monitoring of nutritional status in groups of children and adolescents is important in monitoring public health (14).

The risk factors have an impact on the health of mothers and newborns which was begin in adolescents, including adolescent nutrient deficiencies. The low body mass index significantly increases the risk of perinatal including stillbirth, miscarriage, small for gestational age and low birth weight. Anemia iron deficiency is the highest component causing disability for adolescents (2). Overweight in the pre-pregnancy period is closely related to two main causes of maternal death namely pregnancy hypertension and gestational diabetes which correlate with side effects of pregnancy outcomes such as poor breastfeeding practice, obstructive anesthesia associated with pregnancy complications and infections postpartum (16).

Socioeconomic status can be a risk factor for nutritional problems in adolescents. Father and mother education, working mothers are significant risk factors for adolescents obesity in Gorontalo City (17). Social demographic and economic factors include adolescent age, maternal age, eating habits, residence, income, parents occupation, education level and cultural factors related to nutritional status in adolescents (18-20). Stunting with indicator 
height for age describes the nutritional status of the past which is much influenced by the environment and socio economy (12). Adolescents who are not school, living in rural areas and low socioeconomic tend to become stunting (21).

Nutrition knowledge also one of the factors that influence nutritional status in adolescents. Nutrition knowledge will correlate with nutritional attitudes and behavior in adolescents. Adolescents are a group that ranges from experiencing malnutrition, stunting, and anemia caused by a lack of nutrition knowledge and wrong eating behavior (22). Knowledge is the result of knowing, and the results will be obtained after someone senses a certain object (23). Research in junior high school students in Surakarta shows that $61 \%$ of students still low knowledge about balanced nutrition (24). The study results of Puji, et al. (2012) showed adolescent nutrition knowledge mostly in the low category which was $50,7 \%$ and balanced nutrition behaviors in relatively not good category $52.0 \%(25)$. The research results of Putri, et al. (2012) in students Senior High School 1 Taruntung was showed that he subjects with low knowledge in general have practices eating patterns not variation which amounted $53.3 \%$ (26). Research in Makassar indicates $43.4 \%$ of adolescents have not implemented the balanced nutrition (27).

Nutritional status in adolescents is still a problem in Indonesia included in the Gorontalo province. Base on National Basic Health Survey2013 shows that the nutritional problem among adolescents aged 13-15 years is the nutritional status of stunting in the national $35.1 \%$, lean $11.1 \%$ and obesity $10.8 \%$. While in Gorontalo province shows the prevalence of stunting $37,5 \%$, lean $10.8 \%$ and obesity $10.6 \%$ (28). Based on the National Basic Health Survey data about the nutritional status of adolescents aged 13-15 years shows as much as stunting $25.7 \%$, while Gorontalo province shows stunting groups $33.6 \%$, this indicates that the incidence of stunting adolescents is still above the national rate. While the nutritional status of the body mass index for age shows the prevalences lean $8.7 \%$, obesity $16.0 \%$ and Gorontalo province the prevalence lean $12.3 \%$ and $14.6 \%$ obese (29).

Adolescents as a group vulnerable to experiencing nutritional problems, so the study aims to assess the factors that associated with nutritional status in adolescents.

\section{MATERIALS AND METHODS}

The research method was used quantitative research with cross sectional study design. The study was conducted in Islamic Junior High School 1 Model Limboto, based on the results of research was conducted by Rusdianty (2017) in 11 junior high schools in Limboto, Gorontalo District, it was found that 93 students selected by random sampling were found $28 \%$ obese and $98.9 \%$ overweight students (30). The study conducted from March -April 2018. The research had obtained the recommendation of ethical approval from the Health Research Ethics Committee Faculty of Public Health, Hasanuddin University Number 2256 / UN4.14.8 / TP.02.02 / 2019.

The subjects of the study were taken by accidental sampling with inclusion criteria was followed grade VII - VIII, sign an agreement to be research subject, not ill during data collected the was calculated using large sample with an additional $10 \%$ of drop out estimation. The number of subjects study was 251 students.

The collected data was used in primary and secondary data. Primary data was collected by using a questionnaire that contained socioeconomic status, nutrition knowledge, attitude and practices of balanced nutrition, measurement of nutritional status uses an indicator of body mass index for age $(B M I / A)$ and height for age $(H / A)$. BMI/A and TB/A data were obtained through measurements of body weight and height. Bodyweight measurements using a digital scale with precision $0.1 \mathrm{~kg}$ while body height using measurements using microtoice with precision $0.1 \mathrm{~cm}$. Measurement of upper arm circumference for adolescent girls was obtained by using the upper arm circumference band with precision $0.1 \mathrm{~cm}$. Abdominal circumference measurements using a measuring tape abdominal circumference with precision $0.1 \mathrm{~cm}$. Secondary data was obtained by data was collected from the agency/research location. The collected data nutritional status indicator BMI/A was classified as lean if <-2 SD, normal if -2 to 1 SD and obese $>1$ 
SD while the nutritional status indicator $\mathrm{H} / \mathrm{A}$ was classified as stunting if $<-2$ SD and normal $\geq-2$ SD (31). Nutrition knowledge, attitudes, and practices balance nutrition scores were collected using a standardized questionnaire. Nutrition knowledge questionnaires consist of 19 balance nutrition guideline, nutrient function, impact deficiency or excess of nutrient questions, each correct answer was given score 1 and incorrect answer score 0 (32), nutrition knowledge was categorized low (score $<50$ ) and sufficient (score $\geq 50$ ).

The attitude of balanced nutrition was measured 12 statements related to the message and the principle of balanced nutrition, categorized score 4 strongly agreed, 3 agrees, 2 disagrees and 1 strongly disagrees. The attitude of balanced nutrition divided into negative attitudes (score $<80$ ) and positive attitude (score $\geq 80$ ). The balanced nutritional practice consists of 13 statements about variations in food consumption, physical activity, breakfast, monitoring weight gain and hand washing habits. The practice of balance nutrition was categorized as score 4 frequent, 3 sometimes, 2 rarely and 1 never. Categorized into bad behavior (score $<80$ ) and good behavior (score $\geq 80$ ) (33). Knowledge, attitude, and practice of balanced nutrition questionnaire development were started with validity and reliability to young adolescents with similar characteristics with the subjects in this study.

Data analysis was performed univariate and bivariate analysis. Univariate analysis was obtained a general description of the characteristics, socioeconomic status, nutritional status, score knowledge, attitude and practice of balanced nutrition in adolescents. Bivariate analysis was used to assess the association between socioeconomic status, knowledge, attitude, and practice of balanced nutrition with nutritional status in adolescents using chi-square test. Statistical analysis was using the software package SPPS 16 application.

\section{RESULTS}

\section{Subject socioeconomic characteristics}

Description of socioeconomic status and characteristics of the study of the subjects were
Table 1. Analysis status socioeconomic an individual characteristic

\begin{tabular}{|c|c|c|}
\hline \multirow{2}{*}{ Characteristic } & \multicolumn{2}{|c|}{ Amount } \\
\hline & $n=251$ & $\%$ \\
\hline \multicolumn{3}{|l|}{ Father Education } \\
\hline Not in elementary school & 3 & 1,2 \\
\hline Elementary school & 18 & 7.2 \\
\hline Middle School & 25 & 10.0 \\
\hline High school & 94 & 37.5 \\
\hline Diploma, Bachelor & 111 & 44.2 \\
\hline \multicolumn{3}{|l|}{ Mother Education } \\
\hline Not in elementary school & 3 & 1,2 \\
\hline Elementary school & 12 & 4,8 \\
\hline Middle School & 26 & 10.4 \\
\hline High school & 86 & 34.3 \\
\hline Diploma, Bachelor & 124 & 49.4 \\
\hline \multicolumn{3}{|l|}{ Father occupation } \\
\hline Civil servants & 95 & 37.8 \\
\hline Private employees & 24 & 9.6 \\
\hline Entrepreneur & 83 & 33.1 \\
\hline Labor and farmers & 49 & 19.5 \\
\hline \multicolumn{3}{|l|}{ Mother occupation } \\
\hline Civil servants & 88 & 35.1 \\
\hline Private employees & 10 & 4.0 \\
\hline Entrepreneur & 13 & 5.2 \\
\hline Housewife & 140 & 55.8 \\
\hline \multicolumn{3}{|l|}{ Family Income } \\
\hline$<$ Regional Minimum Wage & 78 & 31.1 \\
\hline$\geq$ Regional Minimum Wage & 173 & 68.9 \\
\hline \multicolumn{3}{|l|}{ Gender } \\
\hline Male & 89 & 35.5 \\
\hline Girl & 162 & 64.5 \\
\hline \multicolumn{3}{|l|}{ Age (years) } \\
\hline 12 years & 5 & 2.0 \\
\hline 13 years & 125 & 48.8 \\
\hline 14 years & 115 & 45.8 \\
\hline 15 years & 6 & 2,4 \\
\hline \multicolumn{3}{|l|}{ Caregivers } \\
\hline Parents & 208 & 82.9 \\
\hline Family & 43 & 17.1 \\
\hline \multicolumn{3}{|l|}{ Number of siblings } \\
\hline$\leq 2$ people & 140 & 55.8 \\
\hline$\geq 3$ people & 111 & 44.2 \\
\hline \multicolumn{3}{|l|}{ Status in family } \\
\hline First child & 111 & 44.2 \\
\hline Second child & 91 & 36.3 \\
\hline Third child & 34 & 13.5 \\
\hline$\geq$ Fourth Child & 15 & 6.0 \\
\hline
\end{tabular}

showed in Table 1. The level of education most of higher education was $44.2 \%$ in fathers and $49.4 \%$ in mothers. The highest percentage of occupational groups were civil servants $37.8 \%$ in fathers and housewives $55.8 \%$ in mothers. The highest income levels above the regional minimum wage were $68.9 \%$. Characteristics subjects of the study was showed percentages of men $64.5 \%$ higher than 
Table 2. Anthropometric measurement, knowledge, attitude, practice of balanced nutrition score

\begin{tabular}{lccc}
\hline \multicolumn{1}{c}{ Nutritional status and z-score } & Mean \pm sd & Min & Max \\
\hline Weight $(\mathrm{kg})$ & $47.31 \pm 11.15$ & 26.70 & 91.00 \\
Height $(\mathrm{cm})$ & $152.68 \pm 6.36$ & 134.70 & 171.90 \\
Abdominal circumference $(\mathrm{cm})$ & $71.21 \pm 10.21$ & 63.00 & 104.00 \\
Upper arm circumference (cm) & $23.67 \pm 4.30$ & 20.00 & 34.50 \\
Nutritional knowledge & $41.89 \pm 12.65$ & 10.53 & 73.68 \\
Attitude & $81.04 \pm 6.95$ & 62.50 & 95.83 \\
Behavior & $71.00 \pm 9.75$ & 38.46 & 96.15 \\
H/A (SD) & $-1.03 \pm 0.85$ & -3.44 & 1.74 \\
BMI/A (SD) & $0.02 \pm 1.36$ & -3.05 & 3.43 \\
\hline
\end{tabular}

Table 3. Association between socioeconomic, knowledge, attitude and practice of balanced nutrition with $\mathrm{H} / \mathrm{A}$

\begin{tabular}{|c|c|c|c|c|c|c|c|}
\hline \multirow{3}{*}{ Variable } & \multicolumn{4}{|c|}{ TB / U } & \multirow{2}{*}{\multicolumn{2}{|c|}{ Total }} & \multirow{3}{*}{ p-value } \\
\hline & \multicolumn{2}{|c|}{ Stunting } & \multicolumn{2}{|c|}{ Normal } & & & \\
\hline & $\mathbf{n}$ & $\%$ & $\mathbf{n}$ & $\%$ & $\mathbf{n}$ & $\%$ & \\
\hline Father education & & & & & & & \\
\hline$<9$ years & 11 & 24.4 & 34 & 75.6 & 45 & 17.9 & .001 \\
\hline$\geq 9$ years & 14 & 6.8 & 192 & 93.2 & 206 & 82.1 & \\
\hline Mother education & & & & & & & \\
\hline$<9$ years & 8 & 19.5 & 33 & 80.5 & 41 & 16.3 & 0.051 \\
\hline$\geq 9$ years & 17 & 8.1 & 193 & 91.9 & 210 & 83.7 & \\
\hline Mother occupation & & & & & & & \\
\hline Work & 9 & 7.8 & 107 & 92.2 & 116 & 46.2 & 0.385 \\
\hline Does not work & 16 & 18.9 & 119 & 88.1 & 135 & 53.8 & \\
\hline Family income & & & & & & & \\
\hline$<$ Minimum regional wage & 8 & 10.3 & 70 & 89.7 & 78 & 31.1 & 1.000 \\
\hline$\geq$ Minimum regional wage & 17 & 9.8 & 156 & 90.2 & 173 & 69.8 & \\
\hline Caregivers & & & & & & & \\
\hline Parents & 19 & 9.1 & 189 & 90.9 & 208 & 82.9 & 0.496 \\
\hline Family & 6 & 13.9 & 37 & 86.1 & 43 & 17.1 & \\
\hline Number of siblings & & & & & & & \\
\hline$\leq 2$ people & 18 & 12.8 & 122 & 87.2 & 140 & 55.8 & 0.131 \\
\hline > 3 people & 7 & 6.3 & 104 & 93.7 & 111 & 44.2 & \\
\hline Gender & & & & & & & \\
\hline Male & 6 & 6.7 & 83 & 92.3 & 89 & 35.5 & 0.298 \\
\hline Female & 19 & 11.7 & 143 & 88.3 & 162 & 64.5 & \\
\hline Knowledge & & & & & & & \\
\hline Low & 17 & 9.3 & 165 & 90.7 & 182 & 72.5 & 0.767 \\
\hline Enough & 8 & 11.6 & 61 & 88.4 & 69 & 27.5 & \\
\hline Attitude & & & & & & & \\
\hline Negative & 12 & 11.4 & 93 & 88.6 & 105 & 41.8 & 0.656 \\
\hline Positive & 13 & 8.9 & 133 & 91.1 & 146 & 58.2 & \\
\hline Behavior & & & & & & & \\
\hline Not good & 11 & 9.6 & 103 & 90.4 & 114 & 45.4 & 1.000 \\
\hline Good & 14 & 10.2 & 123 & 89.8 & 137 & 54.6 & \\
\hline Amount & 25 & 10.0 & 226 & 90.0 & 251 & 100.0 & \\
\hline
\end{tabular}

women $35,5 \%$, the age group most of in 13 years old which was $48.8 \%$, caregivers most of parents $82.9 \%$, the highest number of siblings $\leq 2$ people which was $55.8 \%$ and status in the family most of the first child $44.2 \%$.
Anthropometric, knowledge, attitude, practice of balanced nutrition

Analysis of anthropometric measurements, knowledge, attitudes, and practice of balanced 
nutritional in adolescents were showed in Table 2. The average of anthropometric measurement was weight $47.31 \pm 11.15 \mathrm{~kg}$, height $152.68 \pm 6.36 \mathrm{~cm}$, abdominal circumference $71,21 \pm 10.21 \mathrm{~cm}$, upper arm circumference $23.67 \pm 4.30 \mathrm{~cm}$. The results of the measurement nutritional knowledge scores were $41.89 \pm 12.65$, attitudes $81.04 \pm 6.95$ and practices of balanced nutrition $71.00 \pm 9.75$. The nutritional status BMI/A $0.02 \pm 1.36 \mathrm{SD}$ and $\mathrm{H} / \mathrm{A}$ $-1.03 \pm 0.85$ SD.

Association between socioeconomic, knowledge, attitude and practice of balanced nutrition with $\mathrm{H} / \mathrm{A}$

Analysis of the association between socioeconomic status, knowledge, attitude, and practice with nutritional status in adolescent Indicator high for age $(\mathrm{H} / \mathrm{A})$ was showed in Table 3. Adolescents with stunting $24.4 \%$ with father education $<9$ years lower than adolescents with normal nutritional status which was $75.6 \%$, although the chi-square test $p$-value obtained $=0.001$. Adolescents with stunting $19.5 \%$ with mother education $<9$ years, lower than adolescents with normal nutritional status is $80.5 \%$, the chi-square test obtained $p$-value $=0.051$. There were $7,8 \%$ of adolescents with stunting with working mothers lower than adolescents with a normal nutritional status of $92.2 \%$, the chi-square test obtained $p$-value $=0.385$. Stunting adolescents were $10.3 \%$ with family income below the regional minimum wage lower than adolescents with normal nutritional status which was $89.7 \%$, chi-square test obtained $p$-value $=1,000$. There were $9.1 \%$ of adolescents stunting with a caregiver from their parents, lower than adolescents with normal nutritional status $90.9 \%$, p-value $=0.496$. Adolescents stunting $12.8 \%$ with number of siblings $\leq 2$ people lower than adolescents with normal nutritional status $87.2 \%$, $p$-value $=0.131$.

Analysis of nutritional status based on sex showed that adolescents stunting greater in female $11.7 \%$ than male $6.7 \%$, however the chi-square test showed $p$-value $=0.298$. There were $9.3 \%$ of adolescents who have low knowledge with stunting, lower than normal nutritional status $90.7 \%$, the statistical test results obtained $p$-value $=0.767$ which showed there was no association between knowledge with stunting in adolescents. There were $11.4 \%$ of adolescents have negative attitudes with stunting, lower than the normal nutritional status $88.6 \%$, the statistical test obtained p-value 0.656 which was indicated there no association between attitude of balanced nutrition with stunting in adolescents. There were $9.6 \%$ of adolescents have poor practice balanced nutrition with stunting, lower than the normal nutritional status $90.4 \%$, the statistical test results obtained $p$-value 1,000 which indicated there was no association between practice of balanced nutrition with stunting in adolescents. Overall the results of the study showed there were $10.0 \%$ of adolescents with stunting and $90.0 \%$ normal nutritional status.

Association between socioeconomic, knowledge, attitude and practice of balanced nutrition with BMI/A

Analysis of the socioeconomic status, knowledge, attitude, and practices of balanced nutrition with nutritional status in adolescents based on body mass index for age indicators (BMI/A) was showed in Table 4. Obese adolescents with father education $<9$ years $15,5 \%$ lower than adolescents with normal nutritional status which was $84.5 \%$, the chi-square test in $p$-value $=0.23$. Obese adolescents with maternal education $<9$ years as much as $19.5 \%$ lower than normal nutritional status which was $80.5 \%, p$-value $=0.65$. Obese adolescents with working mothers $27.6 \%$ lower than normal nutritional status which was $72.4 \%$, chi-square analysis obtained $p$-value $=0.206$. Obese adolescents from family income were less than the regional minimum wage $13.4 \%$ lower than adolescents with normal nutritional status which was $84.6 \%$, the results of the chi-square test analysis obtained $p$-value $=0.061$. adolescents who live with both parents as much as $24.5 \%$ obese lower than adolescents with normal nutritional status was $75.5 \%$, the analysis of $p$-value $=0.525$. adolescents with the number of siblings $\leq 2$ as much as $22.9 \%$ was low compared with normal nutritional status which was $77.1 \%$, the chi-square test obtained 
Table 4.Association between socioeconomic, knowledge, attitude and practice of balanced nutrition with BMI/A

\begin{tabular}{|c|c|c|c|c|c|c|c|}
\hline \multirow{3}{*}{ Variable } & \multicolumn{4}{|c|}{ BMI / A } & \multirow{2}{*}{\multicolumn{2}{|c|}{ Total }} & \multirow{3}{*}{ p-value } \\
\hline & \multicolumn{2}{|c|}{ Obesity } & \multicolumn{2}{|c|}{ Normal } & & & \\
\hline & $\mathrm{n}$ & $\%$ & $\mathrm{n}$ & $\%$ & $\mathbf{n}$ & $\%$ & \\
\hline \multicolumn{8}{|l|}{ Father education } \\
\hline$<9$ years & 7 & 15.5 & 38 & 84.5 & 45 & 17.9 & \multirow{2}{*}{0.232} \\
\hline$\geq 9$ years & 52 & 25.3 & 154 & 74.7 & 206 & 82.1 & \\
\hline \multicolumn{8}{|l|}{ Mother education } \\
\hline$<9$ years & 8 & 19.5 & 33 & 80.5 & 41 & 16.3 & \multirow[t]{2}{*}{0.647} \\
\hline$\geq 9$ years & 51 & 24.3 & 159 & 75.7 & 210 & 83.7 & \\
\hline \multicolumn{8}{|l|}{ Mother occupation } \\
\hline Work & 32 & 27.6 & 84 & 72.4 & 116 & 46.2 & \multirow{2}{*}{0.206} \\
\hline Does not work & 27 & 20.0 & 108 & 80.0 & 135 & 53.8 & \\
\hline \multicolumn{8}{|l|}{ Family income } \\
\hline$<$ Minimum regional wage & 12 & 13.4 & 66 & 84.6 & 78 & 31.1 & \multirow{2}{*}{0.061} \\
\hline$\geq$ Minimum regional wage & 47 & 27.2 & 126 & 72.8 & 173 & 68.9 & \\
\hline \multicolumn{8}{|l|}{ Caregivers } \\
\hline Parents & 51 & 24.5 & 157 & 75.5 & 208 & 82.9 & \multirow[t]{2}{*}{0.525} \\
\hline Family & 8 & 18.6 & 35 & 81.4 & 43 & 17.1 & \\
\hline \multicolumn{8}{|l|}{ Number of siblings } \\
\hline$\leq 2$ people & 32 & 22.9 & 108 & 77.1 & 140 & 55.8 & \multirow[t]{2}{*}{0.903} \\
\hline > 3 people & 27 & 24.3 & 84 & 75.7 & 111 & 44.2 & \\
\hline \multicolumn{8}{|l|}{ Gender } \\
\hline Male & 21 & 23.6 & 68 & 76.4 & 89 & 35.5 & \multirow[t]{2}{*}{1.000} \\
\hline Female & 38 & 23.5 & 124 & 76.5 & 162 & 64.5 & \\
\hline \multicolumn{8}{|l|}{ Knowledge } \\
\hline Low & 40 & 22.0 & 142 & 78.0 & 182 & 72.5 & \multirow[t]{2}{*}{0.447} \\
\hline Enough & 19 & 27.5 & 50 & 72.5 & 69 & 27.5 & \\
\hline \multicolumn{8}{|l|}{ Attitude } \\
\hline Negative & 26 & 24.8 & 79 & 75.2 & 105 & 41.8 & \multirow[t]{2}{*}{0.805} \\
\hline Positive & 33 & 22.6 & 113 & 77.4 & 146 & 58.2 & \\
\hline \multicolumn{8}{|l|}{ Behavior } \\
\hline Not good & 31 & 27.2 & 83 & 72.8 & 114 & 45.4 & \multirow[t]{3}{*}{0.268} \\
\hline Well & 28 & 20.4 & 109 & 79.6 & 137 & 54.5 & \\
\hline Amount & 59 & 23.5 & 192 & 76.5 & 251 & 100.0 & \\
\hline
\end{tabular}

value $p$-value $=0.90$. Obese adolescents were more common in adolescent females compared to adolescent males, even though the value of $p$-value $=1,000$. There were $22.0 \%$ of obese adolescents who have low knowledge, lower than the normal nutritional status $78.0 \%$, the statistical analysis test obtained $p$-value $=0.45$ which was showed there no association between nutritional knowledge with the incidence of obesity in adolescents. There were $24.8 \%$ of adolescents have negative attitudes related to nutrition with obese nutritional status, lower than normal nutritional status which was $75.2 \%$, the statistical test obtained $p$-value $=0.80$ which showed there was not association between balanced nutritional attitudes with the incidence of obesity in adolescents. There were $27.2 \%$ of adolescents have poor nutritional practices with obese nutritional status, lower than the normal nutritional status of $72.8 \%$, the statistical test results obtained $p$-value $=0.27$ which indicated there no association between balanced nutritional practice with the incidence of obesity in adolescents.

\section{DISCUSSION}

\section{Subject socioeconomic characteristics}

Adolescents are young people with an age range of 10-19 years, consisting of early adolescents aged $10-13$ years characterized by rapid growth (growth spurt) and early maturation of sexual organs, middle adolescents in the age range between 14-15 years with the characteristics 
of comprehensive physical changes with individual development that is very strong in finding selfidentity, late adolescents in the age range between 16-19 years are characterized by maturity and perfect physical formation of the body that resembles adults (34). Based on WHO criteria, study subjects of the adolescents were in the category of early adolescents and middle adolescents, which characterized by comprehensive physical changes and individual development to self-identity.

\section{Anthropometric, knowledge, attitude, practice of balanced nutrition}

The mean score of nutrition knowledge, nutrition attitudes, practice of balanced nutrition in adolescents were $41.89,81.04$ and 71.00 respectively, the mean score higher than the results of study Patimah et al., (2016) who found the average score nutrition knowledge in adolescent 29.92, balanced nutrition attitude 49.07 and balanced nutrition practice 15.81 (35). The other study which was conducted in Banyumas district was indicated that average score knowledge in adolescents 16.03 in intervention groups and 13,84 in control groups, the study was followed by nutrition education programs (36). The average nutrition knowledge was also higher than in the previous study in Italy which was found the score of nutrition knowledge using questionnaire sell administered (Ques CA) which was 16.6 (37). Nutrition knowledge was higher than in urban area 66.7 and rural areas 66.1 (38).

\section{Association between socioeconomic, knowledge, attitude and practice with H/A}

The results showed that short stature status in adolescents related to father education, while mother education, mother occupation, family income, care givers history, number of siblings, gender did not correlate with short stature in adolescents. Indicator of body height for age $(\mathrm{H} / \mathrm{A})$ is one of the most recommended indicators for detecting malnutrition stunting in adolescents which provides an overview of chronic nutritional problems that shows the history of nutritional status and is heavily influenced by environmental and socioeconomic factors
$(12,31,39)$. Stunting prevalence in this study was $10.0 \%$, the number of this prevalence lower than stunting prevalence in adolescents in Sukoharjo with prevalence of stunting adolescents $23.07 \%$ (40), in Maros stunting prevalence in adolescent girls was $23.6 \%$ (41), the study in Yemen that found $20.0 \%$ of adolescents experienced short stature (42), in India as many as $19.5 \%$ of adolescents with stunting (43), the prevalence of stunting in adolescents $16,3 \%$ was found in Ethiopia (13) and Bangladesh showed the prevalence of stunting in adolescents $25.0 \%$ (44), but lower than the prevalence of stunting in Turkey $4.4 \%$ (45). Adolescents with short stature nutritional status of $10.3 \%$ with family income below the regional minimum wage, this number was lower than previous studies which found that the incidence of stunting in children and adolescents as much as $52.8 \%$ were found in poor families, there was a relationship between social economy with incidence of stunting (21).

There was a different prevalence of stunting in adolescents between urban and rural areas, the incidence of stunting was more common in rural Yemen due to poverty crises in the community, as well as the results of research in India $(21,46)$. Children and adolescents from poor families more experienced stunting $(52,8 \%)$ than in children and adolescents with upper middle-income families $(47.7 \%)$ with a significant difference $(p=0.01)$, the overall prevalence of stunting $49,5 \%$ (21), the same finding research also found in India (47) and Pakistan (48). Research results in Ethiopia found a positive association between adolescent dwellings in rural areas at risk 1.34 times $(\mathrm{AOR}=0.12,95 \% \mathrm{Cl}$ $1.24-2.33$ ) and the habit of not consuming snacks at risk 11.38 times $(\mathrm{AOR}=0.12,95 \% \mathrm{Cl} 1.47-17.8)$ of stunting, on the other side maternal work was negatively correlated with the incidence of stunting (AOR $=0.12,95 \% \mathrm{Cl} 0.17-0.87)$ (13). Research in Bangladesh showed that mother height less than $147.5 \mathrm{~cm}(\mathrm{OR}=2.93,95 \% \mathrm{Cl}=2.06-4.20)$, the level of maternal education (OR $=1.74,95 \%$ $\mathrm{Cl}=1.17-2.81)$ and the conception period were predictors of stunting in pre-adolescent $(p<0.001)$ (49). Another study has shown that the number of siblings related to the incidence of stunting in 
adolescents (41). The differences of findings in this study can be caused by differences in the characteristics of research subjects, differences in research methods and there were still number of risk factors stunting which were not measured in this study, such as eating habits, maternal and paternal factors, immunization history, history of infection, birth weight factors that might also influence the incidence of stunting in adolescents.

\section{Association between socioeconomic, knowledge, attitude and practice of balanced nutrition with $\mathrm{BMI} / \mathrm{A}$}

The prevalence of obesity in adolescents from this study $23.5 \%$. The incidence of adolescent obesity which was found in this study higher than the prevalence of adolescents obesity in the Semarang urban area which was $10.4 \%$ and $22.9 \%$ in the rural area (38). However, the prevalence of adolescent obesity in this study was lower than the results from research in Malaysia which was showed the prevalence of obesity in adolescents $29.4 \%$ in rural area and $28.9 \%$ in urban area (50), as well as the results of research in Taiwan that found the prevalence of overweight and obesity in adolescents $28.1 \%(51)$.

Obesogenic environment including socioeconomic factors also plays an important role in the incidence of obesity. The results showed father education, mother education, mother occupation, family income, history of caregivers, number of siblings, gender not related to obesity in adolescents. This study in line with previous research was stated that the mother education primary school and junior high school did not have significant association with the incidence of overweight in adolescents and there was no association between father and mother education with the incidence of obesity in adolescents $(52,53)$. However, the results of this study were also different from the previous study that found an association between obesity and father education, mother education, mother occupation and low nutritional knowledge (17). Education has an effect to increase awareness for choose healthy foods, which give an impact to practice healthy life and to practice a number of physical activities, on the other hand only families who have enough economic status will try to send their children to school, so this illustrates the positive relationship between quality of life and health status (21). The incidence of adolescent obesity in this study more common in adolescents with family income above regional minimum wage, this study in line with research by Ahmad et al. (2018), who was found the high level of income related to the number of expenditure for food consumption which has an impact on obesity in adolescents (50). However, the results of this study different from the study by $\mathrm{Ni}$ et al. (2019) who found negative association between adolescent obesity with family income $(r=-0.80, p<0.01)(51)$. The research results of Ahmad et al. (2018) was shown that the nutritional status of adolescents in rural areas was not related to the number of family members, mother occupation, father occupation, mother education, and father education, but family income and socioeconomic status were related to adolescent obesity, the incidence of obesity was more common in adolescents with higher education and employment family, while in urban areas the number of family members, mother occupation, father occupation, mother education, father education, income level, and socioeconomic status were associated with the incidence of adolescent obesity, the incidence of adolescent obesity was mostly found in adolescents with high educated families (50). The level of parental education will affect knowledge related to nutrition in parents, thus affecting the practice of providing food for consumption at the family level which can have an impact on adolescent nutritional status.

Knowledge, attitude and behavior of balanced nutrition are not related to nutritional status in adolescents, both short nutritional status and obesity in adolescents. The study was indicated low knowledge of adolescents $72.5 \%$. The results of this study in line with previous study in junior high school students Surakarta, that found about $61 \%$ of students who still lack knowledge about balanced nutritional behavior (24), the students senior high school Negeri 1 Ungaran showed respondents knowledge in the low category $50.7 \%$ (25). However, the percentage of low knowledge category greater 
than previous study in Gorontalo city that found knowledge of nutrition low category only $4.3 \%$ (17), knowledge of malnutrition among adolescents $41.0 \%$ (35), another study which was conducted by Maria (2012) indicated $43.3 \%$ of adolescents have low nutritional knowledge (54), low knowledge in adolescents $31.2 \%$ in Semarang urban areas and $25.5 \%$ in rural areas, the research indicated that there were different trend of nutritional problems between urban and rural areas $(p=0.001)$, although nutritional knowledge $(p=0.87)$ and eating behavior $(p=0.14)$ did not show significant differences (38).

The low knowledge of balanced nutrition in adolescents can be caused by the lack of information sources about balanced nutrition both in the neighborhood and school environment. In this study was found negative attitudes about balanced nutrition $41.8 \%$ and not good practice of balanced nutrition $45.4 \%$. The practice of balanced nutrition on the subject study as much as $54.6 \%$ good practice of balanced nutrition, it was almost same with the previous study that conducted by Puji et al. (2012) showed the behavior of respondents to fulfill balanced nutrition in the good category $48 \%$ (25). Likewise, the results of research in Makassar was showed that $56.6 \%$ of adolescents practice balanced nutrition, while $43.4 \%$ have not implemented balanced nutrition in their daily lives (27). However, the attitude and practice of balanced nutrition score in this study was lower than in Maros studies that indicated negative attitude $55.5 \%$ of balanced nutrition and $46.5 \%$ practice balanced nutrition was not good (35), another study in Egyp found negative attitude about nutrition $66.6 \%$ (55). The results showed a tendency of negative correlation between knowledge with attitude, this in line with research Patimah et al., (2016) (35), lack of knowledge of nutrition research on the subject was precisely correlated negative with balanced nutrition attitude, although the nutrition knowledge of nutrition $72.5 \%$ in low category, but positive attitude balanced nutrition $58.2 \%$, this may be influence of the family environment and the school environment. Base on reinforcement theory of knowledge is not always in line with positive behavior (35). The results of this study were not in line with research in Gorontalo City which found that low nutritional knowledge was the risk factor for adolescent obesity (17). There differences of results study either inline or contradictive with the results of this study, this can be caused of the low variability of nutritional status data of in short stature $(10.0 \%)$ and obesity $(23.5 \%)$ compared to normal nutritional status, differences in the basic characteristics of adolescents as the subject of research, different research locations, there were other variables that not measured in this study, such as energy consumption, macronutrient, and micronutrient and fiber intakes, physical activity and sedentary activity in adolescents, the distribution of data was found more adolescents with low nutritional knowledge with normal nutritional status compared to adolescents with good nutritional knowledge, the research methodology used was different. The low knowledge of adolescent nutrition in this study can be caused by a lack of access to information and exposure to information about nutrition among adolescents, compared to adolescents who live in urban areas.

\section{CONCLUSION AND RECOMMENDATION}

The prevalence of adolescents short stature $10.0 \%$, adolescents obesity $23.5 \%$, low nutritional knowledge $72.5 \%$, negative attitudes balanced of nutrition $41.8 \%$ and poor practice balanced of nutrition $45.4 \%$. However, chi-square test analysis was showed that father education have association with the incidence of stunting in adolescents, but mother education, mother occupation, family income, history of caregivers, number of siblings, gender, knowledge, attitudes, and practice od balanced nutrition were not related to the incidence of stunting and obesity in adolescents. It is recommended to optimize the socialization of balanced nutrition to adolescent groups and monitoring of adolescent nutritional status to detect the incidence of adolescent nutrition problems earlier.

\section{ACKNOWLEDGEMENTS}

Thank you to the Directorate General of Strengthening and Developing Education of 
Indonesia (Ristekdikti) for the assistance provided to the research team, so that this research activity can run well. Thank you to the MTSN Model Limboto who has agreed to become a research location, Gorontalo University Research and Community Service Institute (LP3M) for their assistance during the research.

\section{REFERENCES}

1. Islam MS, Rahman SS, Kamruzzaman M, Raza MS, Saifuzzaman M, Aktar MJ, Hossain MS. Impact of nutrition education on nutritional status of adolescent girls in South-west Region of Bangladesh. American Journal of Nutrition and Food Science. 2015; 2(1): 1 - 6.

2. Salam RA, Hoda M, Das JK, Arshad A, Lassi ZS, Middleton P, Bhutta ZA. Intervention to improve adolescent nutrition: a systematic review and meta-analysis. Journal of asolescent health. 2016; 59: 29 - 39.

3. doAmarel e Melo GR, de Carvalho Silva Vargas F, dos Santos Chagas CM, Toral N. Nutritional interventions for adolescents using information and communication technologies (ICTs): A systematic review. Plos one. 2017; 12(9): 1- 12.

4. deOnis M. The ECOG's eBook on child and adolescent obesity, in European childhood obesity group. World Health Organization. 2015.

5. deOnisM and Habicht JMP. Anthropometric reference data for international use: recommendations from a World Health Organization Expert Committee. American Journal of Clinical Nutrition. 1996; 64(4): 650-658.

6. United Nations Children's Fund (UNICEF). The state of the World's children 2011: adolescencean age of opportunity. New York: UNICEF; 2011.

7. Abahussain NA. Was there a change in the body mass index of Saudi adolescent girls in Al-Khobar between 1997 and 2007 ?. J Family Community Med.2011; 18(2): 49.

8. Black RE, Victora CG, Walker SP, et al. Maternal and child undernutrition and overweight in lowincome and middleincome countries. Lancet. 2013; 382(9890): 427-451.
9. Rokholm B, Baker JL, Sørensen TIA. The levelling off of the obesity epidemic since the year 1999da review of evidence and perspectives. Obes Rev. 2010;11.

10. Janssen I, Katzmarzyk PT, Boyce WF, King MA, Pickett W. Overweight and obesity in Canadian adolescents and their associations with dietary habits and physical activity patterns. J Adolesc Health. 2004; 35: 360-367.

11. Popkin BM, Gordon-Larsen P. The nutrition transition: Worldwide obesity dynamics and their determinants. Int J Obes. 2004;28:2 - 9.

12. World Health Organization, Catalogue of health indicators: a selection of important health indicators recommended by WHO programmes. WHO. Geneva: 1996.

13. Arage G, Assefa M, Worku T. Socio-demographic and economic factors are associated with nutritional status of adolescent school girls in Lay Guyint Woreda, Northwest Ethiopia. Journal Sage. 2019; 7: 1 - 10.

14. Oninla SO, Owa JA, Onayade AA and Taiwo O. Comparative study of nutritional status of urban and rural Nigerian school children.Journal of Tropical Pediatrics. 2007; 53(1): 39-43.

15. Chu SY, Kim SY, Schmid CH, et al. Maternal obesity and risk of cesarean delivery: A meta analysis. Obes Rev. 2007;8:385 - 394.

16. Chan B, Zacharin M. Maternal and infant outcome after pamidronate treatment of polyostotic fibrous dysplasia and osteogenesis imperfect before conception: A report of four cases. J Clin Endocrinol Metab.2017; 91.

17. Ali R dan Nuryani. Sosial ekonomi, konsum sifast food dan riwayat obesitas sebagai faktor risiko obesitas pada remaja. Media gizi Indonesia. 2018; 13(2): 123 - 132.

18. Maiti S, Chatterjee K, Ali KM, et al. Assessment of nutritional status of rural early adolescent school girls in Dantan-II Block, Paschim Medinipur District, West Bengal. Natl J Community Med. 2011; 2(115): 14-18.

19. Prista A, Maia JAR, Damasceno A, et al. Anthropometric indicators of nutritional status: implications for fitness, activity, and health in school-age children and adolescents from 
Maputo, Mozambique. Am J ClinNutr.2003; 77(4): 952-959.

20. Musa DI, Toriola AL, Monyeki MA, et al. Prevalence of childhood and adolescent overweight and obesity in Benue State, Nigeria. Trop Med Int Health.2012; 17(11): 1369-1375.

21. Al - Mansoob MAK and Masood MSA. The relationship between stunting and some demographic and socioeconomic factors among Yemeni children and adolescents. Hindawi advances in public health. 2018; $1-6$.

22. Ramrao GS. Impact of nutrition education on adolescent girls of Purna Maharashtra. Advapplsci res. 2013; 4(1): 386 - 391.

23. Notoatmodjo S. Perilaku Kesehatan dan IImu Perilaku. Jakarta: PT Rineka Cipta; 2007.

24. Rinanti OS. Hubungan asupan zat gizi makro dan pengetahuan gizi seimbang dengan status gizi siswa-siswi di SMP Muhammadiyah 1 Kartasura. [Skripsi]. Surakarta: Universitas Muhammadiyah Surakarta; 2014.

25. Puji W, Pranot HH, Afriani LD. Hubungan antara pengetahuan tentang gizi seimbang dengan perilaku pemenuhan gizi seimbang pada siswa kelas XI SMA Negeri 1 Ungaran. Jurnal Gizi dan Kesehatan. 2012.

26. Putri N, Ernawati N, Albiner S. Perilaku konsumsi gizi seimbang dan status gizi pada remaja putri di SMAN 1 Tarutung tahun 2012. Medan: Universitas Sumatera Utara; 2012.

27. Syam A. Asosiasi body image, perilaku gizi seimbang dengan status gizi mahasiswa baru FKM Unhas. Prodi IImu Gizi FKM UH (ed). Makassar; 2012.

28. Departemen Kesehatan RI. Riset Kesehatan Dasar (Riskesdas) Laporan Nasional 2013. Jakarta: Departemen Kesehatan RI; 2014.

29. Departemen Kesehatan RI. Riset Kesehatan Dasar (Riskesdas) Laporan Nasional 2018. Jakarta: Departemen Kesehatan RI; 2018.

30. Rusdianty S. Analisis faktor yang memengaruhi kejadian obesitas pada remaja di Kabupaten Gorontalo. [Skripsi]. Limboto: Universitas Gorontalo; 2017.

31. Departemen Kesehatan RI. Keputusan Menteri Kesehatan Republik Indonesia Nomor: 1995/
MENKES/SK/XII/2010 tentang standar antropometri penilaian status gizi anak. Jakarta: Kementerian Kesehatan RI, Direktorat Jenderal Bina Gizi dan Kesehatan Ibu dan Anak, Direkorat Bina Gizi. 2011.

32. Djafar M. Dampak pengetahuan dan sikap terhadap tindakan kader posyandu tentang pedoman umum gizi seimbang (PUGS) di Pondok Betung Pondok Aren. Jurnal IImiah Widya. 2014; 2(2): 21 - 25.

33. Safitri NRD. Pengaruh edukasi gizi dengan ceramah dan booklet terhadap peningkatan pengetahuan dan sikap gizi remaja overweight [artikel penelitian]. Semarang: Universitas Diponegoro; 2016.

34. World Health Organization (WHO). Adolescent friendly health services: an agenda for change. WHO. Geneva; 2003.

35. Patimah S, Royani I, Mursaha A, Thaha AR. Knowledge, attitude and practice of balanced diet and correlation with hypochromic microcytic anemia among adolescent school girls in maros district, South Sulawesi, Indonesia. Biomedical research. 2016; 27(1): $165-171$.

36. Sari HP, Subordjo YP, Zaki I. Nutrition education, hemoglobin levels, and nutrition knowledge ofadolescent girls in Banyumas district. Indonesian journal of nutrition and dietetics. 2018; 6(3): $107-112$.

37. Tallarani A, Zabeo A, Ferraretto A. Nutritional knowledge in an Italian population of children, pre-adolescents and adolescents. Public health nutrition. 2013; 17(3): $708-714$.

38. Setyawati VAV danSetyowati M. Karakter gizi remaja putri urban dan rural provinsi Jawa Tengah. Jurnal kesehatan Indonesia. 2015; 11(1): 43-52.

39. WHO. Physical status: the use and interpretation of anthropometry, Report of a WHO Expert Committee. WHO. 1995.

40. Rahmaningrum ZN. Hubungan antara status gizi (stunting dan tidak stunting) dengan kemampuan kognitif remaja di Sukoharjo, Jawa Tengah. Publikasi ilmiah. Universitas Muhammadiyah Surakarta. Surakarta: 2017.

41. Patimah S, Arundana AI, Royani I, Thaha AR. Low socioeconomic status among adolescent 
schoolgirls with stunting. International proceeding of chemical, bologogical and environmental engineering. 2016; 95 (13): 1-6.

42. Jumaan RM. Serum copper, zinc and copper/ zinc ratio and their relationship to age and growth status in yemeni adolescent girls. Sultan Qaboos University Medical Sciences Journal. 2008; 8(3): 291-299.

43. Singh J, Kariwal P, Gupta S, et al. Assessment of nutritional status among adolescents: a hospitalbased cross-sectional study. IntJ Res Med Sci. 2017; 2(2): 620-624.

44. Svefors P. Stunted growth in children from fetal life to adolescence : risk factors, consequences and entry point for prevention - cohort studies in rural Bangladesh. Dissertations. Faculty of Medicine: Uppsala Universit. Bangladesh; 2018.

45. Ozguven I, Ersoy B, ÖzguvenAA, et al. Evaluation of nutritional status in Turkish adolescents as related to gender and socioeconomic status. J Clin Res PediatrEndocrinol.2010; 2(3): 111.

46. Sarkar SR, Saha S, Roy S, Sil SK. Nutritional status of tripuri tribal adolescent boys of West Tripura District.IndianPediatrics. 2012; 49(6): $494-495$.

47. Katoch OR and Sharma A. Socioeconomic factors, living conditions and child undernutrition among school going children in Rural Areas of district Doda, Jammu \& Kashmir, India: A Preliminary Study.Indian Journal of Nutrition. 2016; 3(1): 1-7.

48. Mushtaq MU, Gull S, Khurshid U, Shahid U, Shad MA, and Siddiqui MA. Prevalence and socio-demographic correlates of stunting and thinness among Pakistani primary school children.BMC Public Health. 2011; 11(1).

49. Svefors P, Rahman A, Ekstrom EC, Khan Al, Lindstrom E, Persson LA, Selling KE. Stunted at 10 years. Liner growth trajectories and stunting from birth to pre adolescence in a rural Bangladeshi cohort. Plos one. 2016; 11(3); 1 - 18.

50. Ahmad A, Zulaily N, Shahril MR, Abdullah FEHS, Ahmed A. Association between socioeconomic status and obesity among 12-year-old Malaysian adolescents. Plos one. 2018;13(7); 1 - 11.

51. Ni YL, Chang JH, Chen LH. Investigating the relationship between district-level socioeconomic status and individual obesity in Taiwanese adolescents: A large-scale crosssectional analysis. Scientific reports. 2019; 9(2928); 1 -9.

52. DoustmohammadianA, Abdollahi M, Bonarianzadeh D, Houshiarrad A,Abtahi M. Parental determinans of overweight and obesity in Iranian adolescents: A national survey. Iran J Pediatr. 2012;22(1): $35-42$.

53. Rafiony A, PurbFa MB, Pramantaral DP. Konsumsi fast food dan soft drink sebagai faktor risiko obesitas pada remaja. Jurnal Gizi Klinik Indonesia. 2015;11(4): 170-178.

54. Maria A. Relationship between knowledge, attitude and practice of balanced diet and student nutritional status of Bogor Agricultural University. Bogor Agricultural University. Scientific Repository. 2012.

55. Ibrahim HDF, Ahmed AM, Gadallah MA, Hussien SAM. Body image, eating habits and practice exercises attitudes of female adolescent students at Assiut University. Med. J. Cairo Univ. 2010; 78: 765 - 772. 